versity; Susquehanna University; Syracuse University; Temple University; Texas A\&M University; Texas

Southern University; University of Texas, Richardson; and Yale University.
For more information about the project, please contact Jun Yin, Minority Identification Project, APSA, 1527 New Hampshire Ave., NW, Washington, DC 20036-1206; 202483-2512; minority_id@apsanet.org.

\title{
Midterm 1998 Election, Speaker Resignation, and Impeachment Proceedings-A Heady Atmosphere for 1998-99 Congressional Fellows' Job Search
}

Jeffrey Biggs, American Political Science Association

APSA welcomed 42 Congressional Fellows to DC this past fall for an orientation to the inner workings of Congress and the federal government. After completing a month (and more, in some cases) of training conducted by academics, journalists, current Hill staffers, and former Fellows, the members of CFP's $46^{\text {th }}$ class began looking for jobs in December.
The $105^{\text {th }}$ Congress's full fall of impeachment proceedings, interrupted briefly by the mid-term elections, made securing staff positions more difficult for these Fellows than for last year's class. Most Fellows found work by mid-January, however.

All eight political science Fellows found positions early. David P. Auerswald of George Washington

\section{Northeast Political Science Association}

The Northeast Political Science Association held its annual meeting in Boston between November 12 and 14, 1998. Program Chair Jo Renee Formicola of Seton Hall University oversaw the meeting, which featured over 400 paper presentations. Guest speakers included former governor of the Commonwealth of Massachusetts, the Honorable Michael Dukakis, now with the Northeastern University department of political science, and Matthew Holden Jr. of the University of Virginia and president of the American Political Science Association. In 1999 the NEPSA will again meet in Boston, November 12-13.

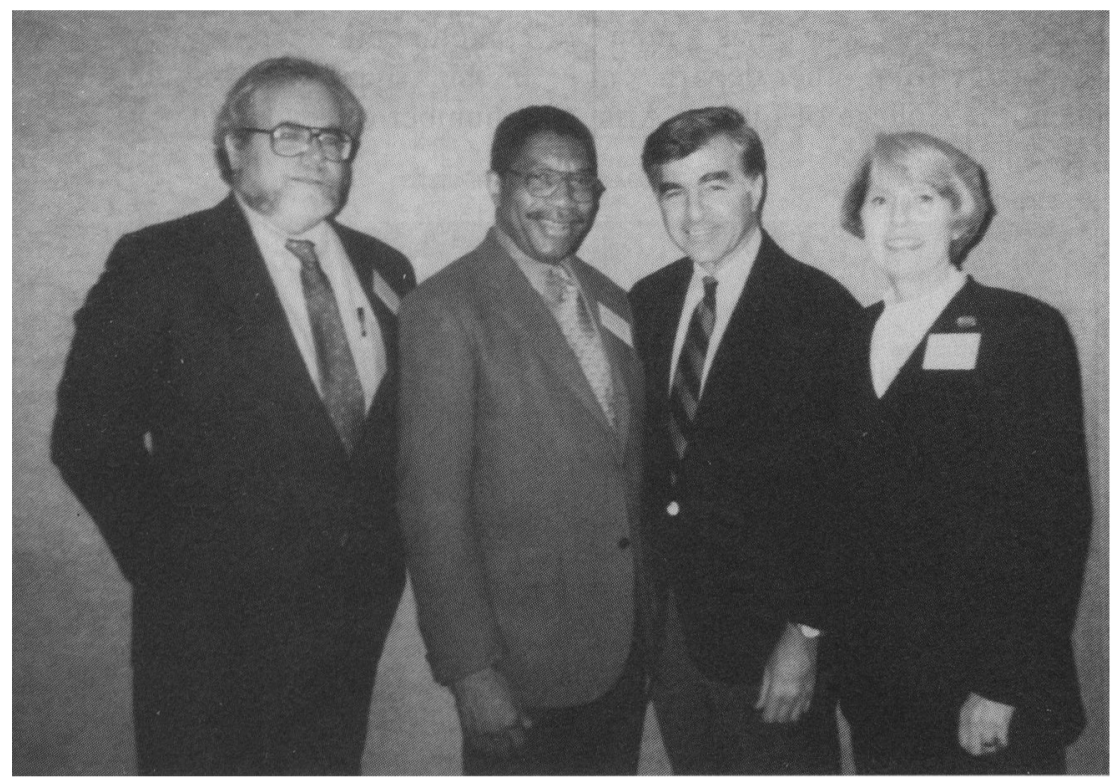

From left to right: Garrison Nelson, Brandeis University (NEPSA Executive Director); Matthew Holden Jr., University of Virginia; the Honorable Michael Dukakis, Northeastern University; and Jo Renee Formicola, Seton Hall University.

University realized his goal of gaining hands-on international relations experience by landing a minority staff position with Senator Joseph Biden (D-DE) on the Senate Foreign Relations Committee. Similarly, Lisa Garcia Bedolla will be able to supplement her doctoral research at Yale University on Latino/a politics with the practical knowledge she gains working for Javier Becerra (DCA), chair of the Hispanic Caucus.

Thomas Brunell, a visiting profes or at the University of California, Irvine, turned his summer job with the House Subcommittee on the Census into a year-long Fellowship assignment dealing with the highly controversial issue of using sampling to supplement the headcount. Colton Campbell, an assistant professor at Florida International University, secured a staff position with Senator Bob Graham (D-FL), and Eric Heberlig of Ohio State University found a position with Ohio Republican Representative Tom Sawyer.

Steiger Fellow David Leal, assistant professor at the State University of New York, Buffalo, parlayed his experience on Senator and perennial-potential presidential candidate's John Kerry's (D-MA) campaign staff into a position on the office staff. Benjamin Highton of the University of California, Berkeley will spend his year in the office of Paul Wellstone (D-MN). APSAMCI Congressional Fellow Daniel Lipinski decided to make maximal use of his Duke University doctoral research on congressional communication with the public by securing a position with the Democratic "message group" chaired by Minority Leader Richard Gephardt (D-MO).

Other Fellows easily making the transition from trainee to employee included first-time Hatfield Fellow Pete Wakefield of the Oregon Grand Rond tribes, whose training as a forester and expertise in landuse management will serve him well as he works in the office of Senator Ron Wyden (D-OR) and serves as a resource person for the entire northwest congressional delegations; Blane Dessy, executive director of the National Library of Education in the U.S. Department of Education, whose interest in the reauthorization of the Elementary and Secondary 